\title{
The Development of Educational Tools (APE) Based on the Environment for Scientific Learning on the Type of Play Development for Teachers of Earthquake Victims in West Praya Sub-District
}

\author{
Baik Nilawati Astini ${ }^{1}$, Ika Rachmayani ${ }^{2}$, Nurhasanah ${ }^{3}$, and Raudatul Jannati ${ }^{4}$ \\ ${ }^{1}$ Early Childhood Department, University of Mataram, Mataram, Indonesia, nilaastini@ymail.com \\ ${ }^{2}$ Early Childhood Department, University of Mataram, Mataram, Indonesia, ikarachma3@gmail.com \\ ${ }^{3}$ Early Childhood Department, University of Mataram, Mataram, Indonesia \\ ${ }^{4}$ Early Childhood Department, University of Mataram, Mataram, Indonesia
}

\begin{abstract}
This research is motivated by the learning process in schools that still have many shortcomings one of which is a limitation of the APE for children. Not only that, an earthquake that occurred in August 2018 ago caused a lot of APE were damaged due to the destruction of the building, exposed to rain, and many lost so that the formulation of the problem of this research is how to model the development of APE, forms APE, and group APE based on the environment which can be used for scientific study on the main types of development for early childhood teachers who became earthquake victims in West Praya sub-district. This type of research is an action research. The research data were collected by questionnaire, focus group discussions, and documents. Data were analyzed using a qualitative descriptive analysis method. These results indicate that the model of development of APE-based environment for learning scientific on the type of game development can be carried out through four stages of the development model of the identification of the source materials for APE-based environment on the kind of man development, grouping materials for APE-based environment on the kind of man development, developing APE based group of materials, and finally the creation of APE for scientific study. The results of questionnaires that have been aggregated into the formula the percentage that the source of many tick is wood with a percentage of $100 \%$, while choosing the least is aluminum with a percentage of $34 \%$, classifying materials for APE divided into two kinds of materials are widely used by teachers, namely 18 organic materials and 6 inorganic materials.
\end{abstract}

Keywords: Scientific Learning, APE

\section{INTRODUCTION}

Games Educational Tool (APE) means to improve child development. Educator or teacher needs a Games Educational Tool (APE) to be taught to children. Where this game tools can also be made with various materials, shapes and the types. Based on the fact there are some schools that use modern or APE APE ready-made and available in schools as well as simple shapes, teachers often forget the true function of the use of the APE. APE purchased teachers are often not used to the maximum and also did not fit the theme of scientific learning for children.

Just as in the area of West Praya, Central Lombok District kindergarten/early childhood are also still using APE finished/existing. After the result of natural disasters that have occurred years ago on the island of Lombok is mainly affected by the earthquake in the area of Central Lombok in Praya Barat place causing some school facilities and equipment damaged many games. So that these teachers have a very limited tool even nothing can be said not to have. While this APE much needed in order to implement the learning process of learning through play. While the APE to be used for learning can be interesting to learn the child and also allows teachers to deliver lessons.

In such cases teachers quake's impact could exploit or create APE by using materials that exist in the environment around. APE also be customized with themes and related to the types of games that are made from materials former. In making this APE does not require a lot of costs so as to help the teachers there. Based on the issues that have been described in the above background, the authors conducted research on the issue and describe it with the title: "Based APE Development Environment for Scientific Learning At Main Type Development, ECD Teachers Earthquake Victims."

The general purpose of this research is to find out the APE development model based on the type of game 
development environment for scientific learning for early childhood teachers who become victims of earthquake in West Praya sub-district. While specifically the purpose of this empirically is (1). To know the shapes of APE-based environment that can be developed for scientific study on the main types of development, early childhood teachers earthquake victims in West Praya sub-district. (2). To group APE-based environment for scientific study on the main types of development, early childhood teachers earthquake victims in West Praya sub-district.

\section{METHODS}

This research was conducted in the District of West Praya, Lombok Barat. Praya Barat sub-district is one of the areas that impact the earthquake last year that caused some schools were damaged including the means and facilities. The study was conducted in February-March 2019. This study will conduct research on the development of APEbased environment for scientific learning on the main types of development in the district of West Praya 2019.,

This type of research used in this study is the kind of action research (Action Research). The population of this research is early childhood teachers of earthquake victims in the District of West Praya which totaled 85 people. Determination of the sample using simple random sampling technique, a sample of this study that $34 \%$ of the population that there will be selected at random from the 85 teacher earthquake victims in the District Praya Barat. So that the number of samples is $34 \% \mathrm{X} 85=28$ people.

Data collection methods used in this study consists of methods: questionnaires, Focus Group Discussion (FGD) and documentation. This research is a qualitative descriptive study conducted with several stages to achieve the research objectives. The stages of the research is as shown in Table 1.

Table: 1 . Stages of Research

\begin{tabular}{|c|c|c|c|}
\hline No & Stages Research & Research activities & Target Outcomes Research \\
\hline 1 & $\begin{array}{l}\text { preparatory } \\
\text { research }\end{array}$ & $\begin{array}{l}\text { 1. } \begin{array}{l}\text { Develop } \\
\text { instruments. }\end{array} \\
\text { 2. } \begin{array}{l}\text { Determination of } \\
\text { subjects. }\end{array}\end{array}$ & $\begin{array}{l}\text { 1. Establishment of research FGD guide. } \\
\text { 2. Establishment of a questionnaire to collect research } \\
\text { data. }\end{array}$ \\
\hline \multirow[t]{3}{*}{2} & \multirow[t]{3}{*}{$\begin{array}{l}\text { Implementation } \\
\text { research. }\end{array}$} & $\begin{array}{l}\text { APE development and data } \\
\text { collection in Group } 1 .\end{array}$ & $\begin{array}{l}\text { 1. Data gathering APE development model. } \\
\text { 2. Data gathering APE forms that can be used for } \\
\text { scientific study on the environmental theme. } \\
\text { 3. APE group of data gathering by the material of } \\
\text { manufacture of the environment for scientific study. }\end{array}$ \\
\hline & & $\begin{array}{l}\text { APE development and data } \\
\text { collection in Group } 2 .\end{array}$ & $\begin{array}{l}\text { 1. Data gathering APE development model. } \\
\text { 2. Data gathering APE forms that can be used for } \\
\text { scientific study on the environmental theme. } \\
\text { 3. APE group of data gathering by the material of } \\
\text { manufacture of the environment for scientific study. }\end{array}$ \\
\hline & & $\begin{array}{l}\text { APE development and data } \\
\text { collection in Group } 3 \text {. }\end{array}$ & $\begin{array}{l}\text { 1. Data gathering APE development model. } \\
\text { 2. Data gathering APE forms that can be used for } \\
\text { scientific study on the environmental theme. } \\
\text { 3. APE group of data gathering by the material of } \\
\text { manufacture of the environment for scientific study. }\end{array}$ \\
\hline 3 & Data analysis & $\begin{array}{l}\text { Analyze the data and draw } \\
\text { conclusions. }\end{array}$ & $\begin{array}{l}\text { Mapping of research results in the form of a development } \\
\text { model APE, APE forms that can be used for scientific study } \\
\text { on the environmental theme and group APE based material } \\
\text { of manufacture of the environment for scientific study. }\end{array}$ \\
\hline 4 & Reporting & Develop a research report. & The arrangement in the form of thesis research report \\
\hline
\end{tabular}

The data analysis is used technique of qualitative data analysis, is to perform the analysis directly result APE has made teachers the earthquake victims in the district of Tanjung with analyzes based on forms of APE can be developed for learning scientific on environmental themes, and classifying APE can be used for scientific study.

\section{RESULT AND DISCUSSION}

Data obtained by using the questionnaire was used to collect data about APE-based environment that can be developed for scientific study on the main types of development. Based on the above table, it can be seen that the percentage of APE material based on the type of game development environment that all checked (YA) by the teacher are wood with the highest percentage reached $100 \%$. APE manufacture materials that are checked on average (YA) by the teacher as much as $71 \%$ that is where the egg (egg tray), tree branches, tin cans and Styrofoam. While choosing the least material is aluminum with $34 \%$.

From the results the percentage of material resources APE manufacture of an environmental based on the type of play development in source materials for APE based material group can be seen in the table $2 \&$ Table 3 below. 
Table. 2. Group Material APE

\begin{tabular}{|r|l|r|r|}
\hline \multirow{2}{*}{ No } & \multicolumn{1}{|c|}{ Name List Making Materials APE } & \multicolumn{2}{|c|}{ Number of Respondents } \\
\cline { 3 - 4 } & & YES & NOT \\
\hline 1 & Wood & 26 & 0 \\
\hline 2 & Foliage & 25 & 9 \\
\hline 3 & Twigs. & 21 & 10 \\
\hline 4 & Flower & 27 & 14 \\
\hline 5 & Banana trees & 33 & 8 \\
\hline 6 & Bamboo & 18 & 2 \\
\hline 7 & coconut fibers & 31 & 17 \\
\hline 8 & Cobblestones. & 24 & 4 \\
\hline 9 & Sand & 22 & 11 \\
\hline 10 & Coral & 28 & 13 \\
\hline 11 & Clay & 27 & 7 \\
\hline 12 & Cereals & 16 & 8 \\
\hline 13 & Cotton & 32 & 19 \\
\hline 14 & Sticks & 18 & 3 \\
\hline 15 & Flannel & 12 & 17 \\
\hline 16 & Aluminum & 14 & 23 \\
\hline 17 & Dacron & 17 & 21 \\
\hline 18 & Yarn & 25 & 18 \\
\hline 19 & Paper & 20 & 10 \\
\hline 20 & Styrofoam & 14 & 15 \\
\hline 21 & Plastic & 15 & 21 \\
\hline 22 & Rubber & 30 & 20 \\
\hline 23 & Former plastic bottles & 33 & 5 \\
\hline 24 & used cardboard & 25 & 2 \\
\hline 25 & Cans & 23 & 10 \\
\hline 26 & Eggshell & 19 & 12 \\
\hline 27 & Nutshell & 24 & 16 \\
\hline 28 & former pipette & 32 & 11 \\
\hline 29 & Former ice cream sticks & 25 & 3 \\
\hline 30 & Eggs tray & 28 & 10 \\
\hline 31 & Close bottles & 16 & 11 \\
\hline 32 & Former plastic glasses & & 7 \\
\hline 33 & Compact Disk (CD) & 19 \\
\hline & & 24 & \\
\hline
\end{tabular}

Table 3. List of Materials Development APE

\begin{tabular}{|c|c|c|c|c|}
\hline Group name & play activities & Materials Used & organic & Inorganic \\
\hline \multirow[t]{3}{*}{ Group 1} & \multirow{3}{*}{$\begin{array}{l}\text { Shows Housekeeping Picture } \\
\text { Card }\end{array}$} & Ice cream stick & $\sqrt{ }$ & \\
\hline & & Paper & $\sqrt{ }$ & \\
\hline & & Cardboard & $\sqrt{ }$ & \\
\hline \multirow[t]{5}{*}{ Group 2} & \multirow{5}{*}{$\begin{array}{l}\text { Geometric Shape Shape compile } \\
\text { Benjadi House }\end{array}$} & Cardboard & $\sqrt{ }$ & \\
\hline & & Flannel & & $\sqrt{ }$ \\
\hline & & Straw & & $\sqrt{ }$ \\
\hline & & Foliage & $\sqrt{ }$ & \\
\hline & & Paper & $\sqrt{ }$ & \\
\hline \multirow{3}{*}{ Group 3} & \multirow[t]{3}{*}{ Develop Puzzle Pieces of Fruit } & Ice cream stick & $\sqrt{ }$ & \\
\hline & & Paper & $\sqrt{ }$ & \\
\hline & & Cardboard & $\sqrt{ }$ & \\
\hline \multirow{4}{*}{ Group 4} & \multirow{4}{*}{$\begin{array}{l}\text { Geometric Shape to be made at } \\
\text { School }\end{array}$} & Cardboard & $\sqrt{ }$ & \\
\hline & & Paper & $\sqrt{ }$ & \\
\hline & & Ice cream stick & $\sqrt{ }$ & \\
\hline & & Twig & $\sqrt{ }$ & \\
\hline \multirow{4}{*}{ Group 5} & \multirow[t]{4}{*}{ Creating Forms Home } & Styrofoam & & $\sqrt{ }$ \\
\hline & & Ice cream stick & $\sqrt{ }$ & \\
\hline & & Paper & $\sqrt{ }$ & \\
\hline & & plastic bottles & & $\sqrt{ }$ \\
\hline \multirow{5}{*}{ Group 6} & \multirow[t]{5}{*}{ Introduce Shape Geometry } & Styrofoam & & $\sqrt{ }$ \\
\hline & & Cardboard & $\sqrt{ }$ & \\
\hline & & Paper & $\sqrt{ }$ & \\
\hline & & Flannel & & $\sqrt{1}$ \\
\hline & & Ice cream stick & $\sqrt{ }$ & \\
\hline Total & & & 18 & 6 \\
\hline
\end{tabular}


Based on the results of grouping the main types of construction materials has brought the teachers in training and seminar amount of organic materials and inorganic No 186 types of materials.

Table 4. Material

\begin{tabular}{|l|l|l|}
\hline $\begin{array}{l}\text { Use of Materials APE } \\
\text { By Respondents type } \\
\text { of Material }\end{array}$ & $\begin{array}{l}\text { Name of } \\
\text { Material }\end{array}$ & $\begin{array}{l}\text { Total } \\
\text { Many } \\
\text { Materials }\end{array}$ \\
\hline Organic & Foliage & 1 \\
\cline { 2 - 3 } & Scrap paper & 6 \\
\cline { 2 - 3 } & used cardboard & 3 \\
\cline { 2 - 3 } & Cardboard & 2 \\
\cline { 2 - 3 } & $\begin{array}{l}\text { Former ice cream } \\
\text { sticks }\end{array}$ & 5 \\
\cline { 2 - 3 } & twig & 1 \\
\hline Total & former straws & 1 \\
\hline Inorganic & Plastic bottles & 1 \\
\cline { 2 - 3 } & Styrofoam & 2 \\
\cline { 2 - 3 } & Flannel & 2 \\
\hline Total & & $\mathbf{6}$ \\
\hline
\end{tabular}

Table 4 above is the use of APE that has been used by the respondent to the training and seminar-based APEmaking environment in the District of West Praya. It can be seen that the organic material APE manufacture the most widely used is waste paper and ice cream sticks used by six groups, three groups using cardboard, two groups using cardboard, leaves one group, and that using the existing tree branch 1 group. Whereas in the group of inorganic materials, the material most widely used APE namely former and Styrofoam flannel cloth used by two groups, one group using plastic bottles and one group using a straw.

APE development model consists of four ways or steps that model to identify the source materials for APE, APE-making materials group model, a model developed the material into a model of how to play the APE and APE. From some of the APE development models, models with regard to the scientific study on the last model namely how to play the APE. Where in this model would explain the stages play APE relating to scientific learning. one example of the step or how to play the scientific APE APE group 2 Ask children to cut out a pattern in the form of geometry, Children sticking flannel with cardboard that has followed the pattern, after the children were asked to draw the pattern into a home.

Steps play APE scientific also found in APE results of group 5 that is made form home with steps are Prepare styrofoam as the base, then put the stick of ice cream into a form of school, scissors and glue paper origami as the doors and windows of the school, and then son tells of his work.

Additionally, APE can be used for scientific learning is APE APE can be coupled with other like putting together a geometric shape for this kind of play-APE APE development which complement each other so as to create the stages of learning scientific activities.

Based on the exposure that has been described above, the conclusion of researchers who can be taken are:

1. Model development tools, educational games (APE) based environment for learning scientific on the theme of the environment for early childhood teachers victims of earthquake in the District of West Praya Central Lombok can do with four models of the development of the identification of the source materials for APE environmentally based on the type of game development, classifying materials manufacture APE environment based on the type of construction play, develop APE based grouping, created APE for scientific study.

2. The forms of APE-based environment that has been developed by teachers for this kind of game development as much as 6 APE which shows part of the house by using card images, compose geometric shapes into the shape of the house, Making Pieces of Puzzle Fruit, Preparing geometric shapes into the shape of a house, Making home form, introducing geometric shapes. APE shape that can be used in scientific study is to develop a geometric shape for this kind of game development.

3. APE making materials group on environmental themes divided into two types: organic and inorganic materials. Of the two types of materials are widely used by teachers, namely cardboard boxes, cardboard, twigs, leaves, paper, stick ice cream the amount of material used is 18 organic matter and while ingredients anorganic used by teachers are straws, flannel, plastic bottles, and styrofoam with number 6 ingredients.

\section{CONCLUSION}

Games Educational Tool (APE) means to improve child development. Educator or teacher needs a Games Educational Tool (APE) to be taught to children. This research findings indicate that the model of development of APE-based environment for learning scientific on the type of game development can be carried out through four stages of development model of the identification of the source materials for APE-based environment on the kind of man development, grouping materials for APE-based environment on the kind of man development, developing APE based group of materials, and finally the creation of APE for scientific study. The results of questionnaires that have been aggregated into the formula the percentage that the source of many tick is wood with a percentage of $100 \%$, while choosing the least is aluminum with a percentage of $34 \%$, classifying materials for APE divided into two kinds of materials are widely used by teachers, namely 18 organic materials and 6 inorganic materials. 


\section{REFERENCES}

[1] Guslinda dan Rita Kurnia. 2018. Media

Pembelajaran Anak Usia Dini. Surabaya:

CV.Jakad Publishing

[2] Hasnida. 2015. Media Pembelajaran Kreatif Mrndukung Pembelajaran Pada Anak Usia Dini. PT Luxima Metro Media. Jakarta Timur.

[3] Laili, RahmaniaAlfi, dkk. 2017. "Meningkatkan Kreativitas Anak Usia Dini Melalui Pembuatan Alat Permainan Edukatif (Ape)" Dalam Penamas Adi Buana Volume 02 (hlm.42-43). Surabaya: Universitas PGRI Adi Buana) (diakses 6 januari 2019)

[4] Latif, Mukhtar. Et al. 2013. Orientasi Baru Pendidikan Anak Usia Dini. Jakarta: Kencana Prenada Media Grup

[5] Mariyaningsih, Nining dan Mistina Hidayat. 2018. Bukan Kelas Biasa: Teori Dan Praktik Berbagai Model Dan Metode Pembelajaran Menerapkan Inovasi Pembelajaran Di Kelas-Kelas Inspiratif. Surakarta: Percetakan CV Oase Group

[6] Mulyatiningsih, Endang. 2014. Metode Penelitian Terapan Bidang Pendidikan. Bandung: Alfabeta.

[7] Ndary, Selaras Susanty dan Chandrawary. 2018. Telaah Kurikulum Pendidikan Anak Usia Dini. Jakarta: Edu Publisher

[8] Prastowo, Andi.2017. Menyusun Rencana Pelaksanaan Pembelajaran (RPP) Tematik Terpadu Impelentasi Kurikulum 2013 Untuk SD/MI. Jakarta: Kencana

[9] Ramadhan, Sarah ZahroNauli. 2018. Pengaruh Aktivitas Bermain Menggunakan Bahan Alam Terhadap Kemampuan Mengklasifikasi Benda Pada AnakUsia 5-6 Tahun. Tesisi S1. Universitas Lampung

[10] Rusman. 2017. Belajar Dan Pembelajaran: Berorientasi Standar Proses Pendidikan. Jakarta: Kencana 